Short communication

\title{
Strain diversity of Rickettsia amblyommatis in ticks infesting birds in the North Huetar conservation area of Costa Rica
}

\author{
Gaby Dolz $^{\mathrm{a}, *}$, Ruth Castro ${ }^{\mathrm{a}}$, Ana E. Jiménez-Rocha ${ }^{\mathrm{a}}$, Mónica Retamosa ${ }^{\mathrm{b}}$, Alberto Alberti ${ }^{\mathrm{c}}$ \\ ${ }^{a}$ Escuela de Medicina Veterinaria, Universidad Nacional, P.O. Box 86-3000, Heredia, Costa Rica \\ ${ }^{\mathrm{b}}$ Instituto Internacional en Conservación y Manejo de Vida Silvestre, Universidad Nacional, P.O. Box 86-3000 Heredia, Costa Rica \\ ${ }^{\mathrm{c}}$ Mediterranean Center for Disease Control/Department of Veterinary Medicine, University of Sassari, Via Vienna 2, 07100 Sassari, Italy
}

\section{A R T I C L E I N F O}

\section{Keywords:}

Multilocus analysis

Amblyomma geayi

Amblyomma longirostre

resident birds

Migrating birds

Central America

\begin{abstract}
A B S T R A C T
Although the presence of rickettsial agents in ticks infesting wild birds in Costa Rica has been recently reported, information on strain diversity is limited to selected rickettsial species. In order to mine deeper into rickettsial agents of ticks infesting Costa Rica wild birds a total of 399 birds from the North Huetar Conservation Area of Costa Rica were captured, and 134 immature ticks (76 larvae and 58 nymphs) were recovered from 61 birds. Ticks were tested for the presence of Rickettsia spp. by conventional PCR and sequencing of the gltA, ompA, ompB, $17 \mathrm{kDa}$, and groEL genes. Six (11.3\%) Amblyomma longirostre and Amblyomma geayi ticks collected from passeriform birds, yielded amplicons of the expected size. Amplicons were sequenced, and BLAST results collectively showed that all sequences had 99-100\% nucleotide identity with Rickettsia amblyommatis (formerly, 'Candidatus Rickettsia amblyommii'). Three different $R$. amblyommatis strains were identified. Four new tick species-host associations and the first detection of $R$. amblyommatis in A. geayi in Costa Rica are also reported.
\end{abstract}

\section{Introduction}

Birds play an important epidemiological role in tick-borne diseases by transferring and disseminating pathogenic bacteria around the world. Migratory species can cover long distances favoring the establishment of these pathogens in new areas and in novel hosts. Extensive research efforts were put on bird-tick-bacterium associations in the American continent, mainly in Brazil (Ogrzewalska et al., 2013; Santolin et al., 2013; Ramos et al., 2015). However, several studies revealed associations also in other countries, such as the United States (Mukherjee et al., 2014), Honduras (Novakova et al., 2015), and Peru (Ogrzewalska et al., 2012).

Recently, the presence of three rickettsial agents infecting ticks sampled from wild birds were reported in Costa Rica: Rickettsia amblyommatis (formerly, 'Candidatus Rickettsia amblyommii') in Amblyomma longirostre, Rickettsia bellii in Amblyomma sabanerae, and a novel Rickettsia sp. agent in Ixodes minor (Ogrzewalska et al., 2015). Considering that Costa Rica's avian biodiversity is one of the highest in the world ( 900 bird species), it can be postulated that most bird-tick-bacterium associations are still to be uncovered. The aim of the present study was to evaluate the strain diversity of Rickettsia spp. found in ticks parasitizing wild birds in Northern Costa Rica throughout a multilocus analysis.

\section{Material and methods}

Ethical statement: The present study was conducted according to the legal requirements of Costa Rica.

Birds from the North Huetar Conservation Area of Costa Rica were captured during a sampling campaign conducted from February 2008 to June 2010, examined for ectoparasites, and released. In total, 134 immature ticks (76 larvae and 58 nymphs) were recovered. Tick specimens were identified at genera level following taxonomic keys (Fairchild et al., 1966). Genomic DNA was extracted from tick pools with Blood and Tissue kit (Qiagen, Hilden, Germany) according to the manufacturer`s instructions. The detection of Rickettsia spp. was performed by conventional polymerase chain reaction (PCR) and sequencing. Genes gltA and ompA were amplified following the protocols described by Labruna et al. (2004) and Regnery et al. (1991), respectively. Three additional genes were amplified for Rickettsia spp.-positive samples: ompB (Choi et al., 2005), $17 k D a$ (Webb et al., 1990), and groEL (Chisu et al., 2016), as well as the molecular determination of the tick species, amplifying mitochondrial 16S rDNA (Norris et al., 1996).

PCR reactions contained a final concentration of $1 \mathrm{X}$ DreamTaq Polymerase Master Mix (ThermoScientific), $0.2 \mathrm{u} \mathrm{M}$ of each primer, $20 \mathrm{ng} / \mathrm{ul}$ DNA sample and water until 25 ul final volume was reached.

\footnotetext{
* Corresponding author.

E-mail addresses: gaby.dolz.wiedner@una.ac.cr, ruth.castro.vasquez@una.ac.cr (G. Dolz), ana.jimenez.rocha@una.ac.cr (A.E. Jiménez-Rocha), mretamos@una.ac.cr (M. Retamosa), alberti@uniss.it (A. Alberti).
} 
Rickettsia felis DNA-positive control was kindly donated by Centro de Investigaciones Regionales Dr. Hideyo Noguchi, Universidad Autónoma de Yucatan, Merida, Mexico. Molecular biology grade water (Fermentas ${ }^{\circ}$ ) was used as negative control in all the cases.

The expected fragment size of each gene was $401 \mathrm{bp}$ for gltA, $532 \mathrm{bp}$ for ompA, $407 \mathrm{bp}$ for ompB, $434 \mathrm{bp}$ for $17 \mathrm{kDa}, 508 \mathrm{bp}$ for groEL, and $462 \mathrm{bp}$ for $16 \mathrm{~S}$ rRNA. Amplicons were visualized in 1\% agarose gels stained with GelRed $^{\mathrm{Tn}}$ Nucleic Acid Gel Stain (Biotium, $5 \mu \mathrm{g} / \mathrm{ml}$ ), and positive samples were sent to Macrogen (Seoul, Korea) for sequencing. Partial sequences were edited with BioEdit (Hall, 1999) to remove primer sequences. Alignments were made by MUSCLE (Edgar, 2004) and phylogenetic trees were constructed with MEGA7 (Kumar et al., 2016) using the Maximum-Likelihood method. Bootstrap of 1000 replicates were used to determine statistical strength of relationships between the clades.

\section{Results}

A total of 399 birds belonging to 45 species and 17 families were captured, and 134 ticks (76 larvae and 58 nymphs) were recovered from $61(15.3 \%)$ animals. Ticks were identified down to genus level as Amblyomma spp. (Supplemental Table 1). A total of six (11.3\%) out of 54 tick pools analyzed yielded amplicons of the expected size in the different PCRs. BLAST results showed that all sequences were $99-100 \%$ identical to $R$. amblyommatis and determined the ticks as A. longirostre $(\mathrm{n}=4)$ and Amblyomma gaeyi $(\mathrm{n}=2)$. Three distinct $R$. amblyommatis strains were identified by multilocus approach. Analyses of the five genes ( $g l t A, o m p A, o m p B, 17 \mathrm{kDa}$ and groEL) of the three identified strains (strain 1 [S1], strain 2 [S2], strain 3 [S3]) by bird and tick species are shown in Table 1 . The first strain was identified in $A$. longirostre collected from Phaenostictus mcleannani. The second strain was found in Amblyomma geayi recovered from Glyphorhynchus spirurus and Thamnophilus atrinucha. The third strain was detected in three $A$. longirostre ticks infesting Dendrocincla fuliginosa, Attila spadiceus and Catharus ustulatus. All these bird species belong to the order Passeriformes and are resident species, except $C$. ustulatus. Except for $D$. fuliginosa and $P$. mcleannani all these tick-host associations were never been observed to date.

Sequences were deposited at the National Center of Biotechnology Information (NCBI) GenBank database, under the following accession numbers: gltA (MG712728, MG712729 and MG712730); ompA (MG787411, MG787412 and MG787413); ompB (MH567002); 17 kDa (MH567004); and groEL (MH567003). Only one representative sequence was submitted for the last three genes, since sequences were identical between strains. Additionally, mitochondrial 16S rDNA gene sequences of A. longirostre (MK605928, MK605929, MK605930 and MK605931) and A. geayi (MK605932 and MK605933) were deposited at the NCBI GenBank. Sequences of $A$. longirostre were $98-100 \%$ identical to sequence KF702347 from Costa Rica and sequences of $A$. geayi were $96 \%$ identical to sequence KM042851 from Brazil.

Amplified fragments from gtlA gene strain 1 were found to be $100 \%$ (350/350) identical to corresponding sequence KX099898 recovered from southeast Brazil, the strain 2 was 100\% (350/350) identical to the sequence KF179351 from Paraguay, and the strain 3 showed $100 \%$ (350/350) identity with KF7023310 from Costa Rica. Furthermore, sequence from ompA gene strain 1 was $100 \%$ (509/509) identical to KM262194 from the northeast Brazil and strain 2 showed 100\% (488/ 488) identity with EU274656 from Sao Paulo, while strain 3 showed $100 \%$ (489/489) identity with MF034496 from Colombia. Analyses of $17 k D a$ gene showed 99\% (366/367) identity with KJ534311 from Brazil. The ompB and groEL sequences were 100\% (403/403) and 99\% (468/470) identical with their corresponding genes in a $R$. amblyommatis complete genome record isolated from Argentina (CP015012).

Phylogenetic analyses were based on a 695 bp-concatenated sequence of gltA (315 bp) and ompA (380 bp), the two most informative genes representative of Rickettsia spp. BLAST results and phylogeny confirmed the presence of three strains of $R$. amblyommatis in ticks harbored by birds in Costa Rica (Fig. 1). Furthermore, R. amblyommatis is reported for the first time in A. geayi in Costa Rica.

\section{Discussion}

Strain diversity of $R$. amblyommatis was investigated in tick from birds in Costa Rica, and the evolutionary relationships with other South American strains were investigated through a multilocus approach. Results provide additional evidence on the expansion of areal distribution of rickettsial pathogens through ticks hosted by birds, and increase our knowledge on the role of ticks as relevant vector for spreading bacterial diseases. Four new rickettsial hosts, and novel tick species-host associations (A. longirostre on A. spadiceus and C. ustulatus, A. geayi on $G$. spirurus and T. atrinucha) were identified. The association of $A$. longirostre with $C$. ustulatus, has particular relevance in the epidemiological scenario, for $C$. ustulatus being a migrating species (Cohen et al., 2015).

Rickettsia amblyommatis had been reported infecting many species of Amblyomma ticks in the Western Hemisphere, showing ability to circulate between different tick species and animal hosts (Labruna et al., 2011). In this study, most of the $R$. amblyommatis infected ticks were found on resident passerine birds (Barrantes et al., 2016; Garrigues et al., 2018), this diminishing their role on dispersing infected ticks over long distances. However, finding an infected tick on C. ustulatus, a medium-sized thrush that lives in North America, and migrates as far as to Argentina, suggests that this wild bird species could play a role in dispersing $R$. amblyommatis infected ticks (Wilson et al., 2008; Mukherjee et al., 2014; Cohen et al., 2015). It is important to stress that $R$. amblyommatis is considered a human pathogen that can cause spotted fever illness, as established based on serological evidence in the United

Table 1

BLAST results comparing the sequences obtained in this study by bird and tick species with the GenBank database.

\begin{tabular}{|c|c|c|c|c|c|c|c|c|c|}
\hline \multirow[t]{2}{*}{ Sample } & \multirow[t]{2}{*}{ Bird species } & \multirow[t]{2}{*}{ Tick species } & \multirow[t]{2}{*}{ Ticks } & \multirow[t]{2}{*}{ Strain } & \multicolumn{5}{|c|}{ GenBank sequences } \\
\hline & & & & & gltA & ompA & ompB & $17 \mathrm{kDA}$ & groEL \\
\hline 47 & $\begin{array}{l}\text { Phaenostictus } \\
\text { mcleannani }\end{array}$ & $\begin{array}{l}\text { Amblyomma } \\
\text { longirostre }\end{array}$ & $2 \mathrm{~L}$ & S1 & KX099898 (100) & KM262194 (100) & $\begin{array}{l}\text { CP015012 } \\
(100)\end{array}$ & $\begin{array}{l}\text { KJ534311 } \\
(100)\end{array}$ & СР015012 (99) \\
\hline 43 & Glyphorhynchus spirurus & Amblyomma geayi & $1 \mathrm{~L}$ & $\mathrm{~S} 2$ & KF179351 (100) & EU274656 (100) JN126316 & СР015012 & KJ534311 & СР015012 (99) \\
\hline 44 & Thamnophilus atrinucha & Amblyomma geayi & $1 \mathrm{~L}$ & & & (99) & $(100)$ & $(100)$ & \\
\hline 51 & Attila spadiceus & $\begin{array}{l}\text { Amblyomma } \\
\text { longirostre }\end{array}$ & $2 \mathrm{~N}$ & S3 & KF702331 (100) & MF034496 (100) & $\begin{array}{l}\text { CP015012 } \\
(100)\end{array}$ & $\begin{array}{l}\text { KJ534311 } \\
(100)\end{array}$ & СР015012 (99) \\
\hline 52 & Catharus ustulatus & $\begin{array}{l}\text { Amblyomma } \\
\text { longirostre }\end{array}$ & $1 \mathrm{~L}$ & & & & & & \\
\hline 16 & Dendrocincla fuliginosa & $\begin{array}{l}\text { Amblyomma } \\
\text { longirostre }\end{array}$ & $3 \mathrm{~L}$ & & & & & & \\
\hline
\end{tabular}

L: Larva, N: Nymph. 


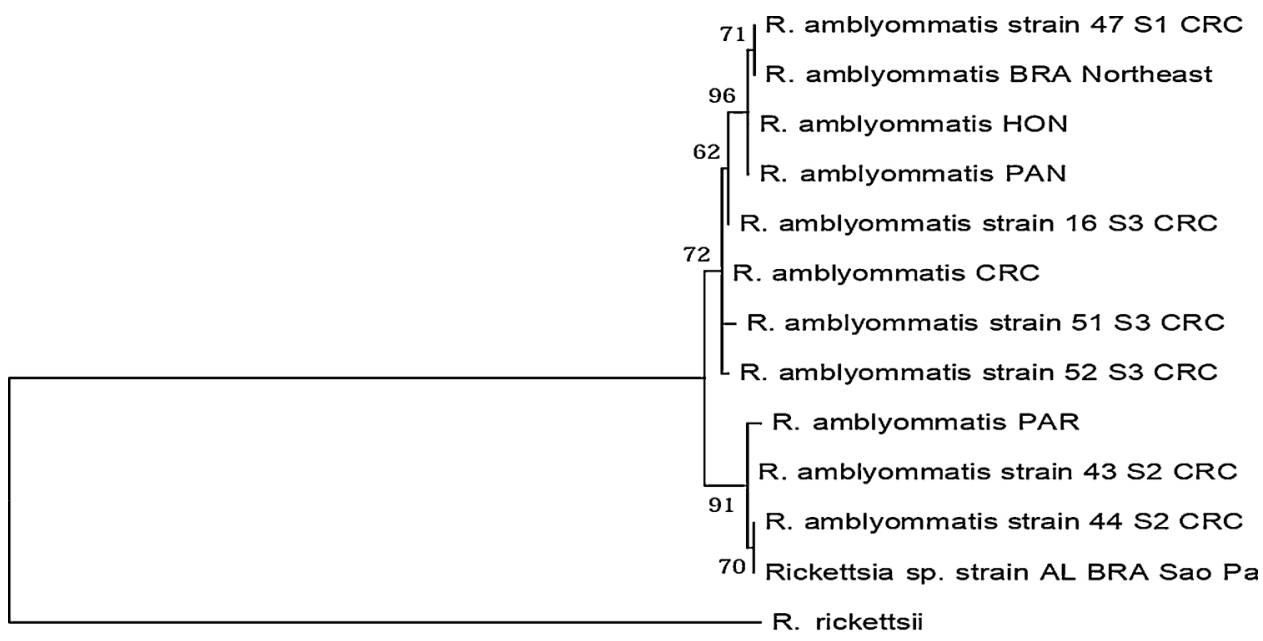

Fig. 1. Phylogenetic tree of $R$. amblyommatis detected in ticks removed from birds in different countries. The analyses were based on a concatenated sequence of gltA (315bp) and ompA (380 bp) genes of 695 bp size and inferred by the maximum-likehood method. Molecular phylogenetic analysis by Maximum Likelihood method on the Tamura-3-parameter model. The percentages of replicate trees in which the associated taxa clustered together in the bootstrap test (1000 replicates) are shown next to the branches. GenBank accession numbers of both genes for all taxons included in this tree were: $R$. amblyommatis BRA Northeast (gltA KM262197, ompA KM262194), R. amblyommatis HON (gltA KP835792, ompA KP835795), $R$. amblyommatis PAN (gltA HM582335, отрA HM582336). $R$. amblyommatis CRC (gltA KF702331, ompA KF702333), $R$. amblyommatis PAR (gltA KF179351, ompA KF179350), Rickettsia sp.

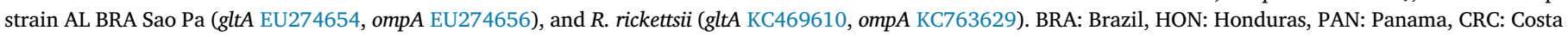
Rica, PAR: Paraguay.

States (Apperson et al., 2008; Vaughn et al., 2014). Furthermore, two of six guinea pigs infected with a Costa Rican strain of R. amblyommatis developed orchitis (Rivas et al., 2015). It has been hypothesized that people in Latin America infected with this bacterium do not show clinical signs or develop disease due to infections with other spotted fever group rickettsiae that provide cross-immunity and protection (Troyo et al., 2016).

Bacteria belonging to the spotted fever group have been molecularly characterized by using several genes as molecular probes; it has been reported that gltA and $17 \mathrm{kDa}$ represent less informative genes than ompA and ompB (Labruna et al., 2004). Also, groEL gene, which encodes a heat shock protein, has been used for diagnosis and phylogenetic analysis of rickettsial agents (Lee et al., 2003; Chisu et al., 2016). In our study ompA and gltA proved to be the most informative genes to distinguish between strains of $R$. amblyommatis, while ompB, $17 \mathrm{kDa}$ and groEL amplicons yielded identical results between strains. For this reason, we consider that it is important to use a multilocus approach when performing intraspecific analysis, not only because it increases the available genetic information of the species studied, but also, because it is possible that the variation found is present in genes that are normally considered highly conserved.

Phylogenetic analyses with a concatenated sequence of ompA and gltA genes were supported by high bootstrap values ( 70 ) confirming the association between Costa Rican and South American strains. Especially, the second strain (S2), which was identified in C. ustulatus, seems to be related with South American strains, while the third strain (S3) was related to a previously reported Costa Rican isolate (GenBank KF702333) and strain one (S1) clustered with isolates from Central and South American countries, seeming to be a more widespread strain. A recent study reported new $R$. amblyommatis sequences in Costa Rica (Troyo et al., 2016), however we could not make any comparison as only one gene ( $g l t A$ or ompA) was sequenced. However, gltA sequences KX544805, KX544806, KX544812 shared 99.7\%, 99.1\% and 99.4\%, of identity with our strain one (S1), respectively; while ompA sequence KX544815 was also 99.7\% (462/463) identical with our strain one (S1).

\section{Conclusions}

Strain diversity of $R$. amblyommatis was assessed in bird ticks in Costa Rica indicating intraspecific variation.

\section{Acknowledgements}

This investigation was supported by the Fondo Especial para el Financiamiento de la Educacion Superior, Consejo Nacional de Rectores (FEES-CONARE). We wish to thank Area de Conservación Huetar Norte for the research permits, Angie Sánchez Nuñez and Carol Sánchez Nuñez for sample collection and the farm owners who provided access to their properties.

\section{Appendix A. Supplementary data}

Supplementary material related to this article can be found, in the online version, at doi:https://doi.org/10.1016/j.ttbdis.2019.06.007.

\section{References}

Apperson, C.S., Engber, B., Nicholson, W.L., Mead, D.G., Engel, J., Yabsley, M.J., Dail, K., Johnson, J., Watson, D.W., 2008. Tick-Borne Diseases in North Carolina: is "Rickettsia amblyommii" a possible cause of rickettsiosis reported as Rocky Mountain spotted Fever? Vector Borne Zoonotic Dis. 8, 597-606. https://doi.org/10.1089/vbz.2007 0271.

Barrantes, G., Ocampo, D., Ramírez-Fernández, J.D., Fuchs, E.J., 2016. Effect of fragmentation on the Costa Rican dry forest avifauna. Peer J Preprints 4, e1970v1. https://doi.org/10.7287/peerj.preprints.1970v1.

Chisu, V., Zobba, R., Foxi, C., Pisu, D., Masala, G., Alberti, A., 2016. Molecular detection and groEL typing of Rickettsia aeschlimannii in Sardinian ticks. J. Parasitol. Res. 115, 3323-3328.

Choi, Y.J., Jang, W.J., Kim, J.H., Ryu, J.S., Lee, S.H., Park, K.H., Paik, H.S., Koh, Y.S., Choi, M.S., Kim, I.S., 2005. Spotted fever group and typhus group rickettsioses in humans, South Korea. Emerg. Infect. Dis. 11, 237-244.

Cohen, E.B., Auckland, L.D., Marra, P.P., Hamer, S.A., 2015. Avian migrants facilitate invasions of neotropical ticks and tick-borne pathogens into the United States. Appl. Environ. Microbiol. 81, 8366-8378.

Edgar, R.C., 2004. Muscle: multiple sequence alignment with high accuracy and high throughput. Nucleic Acids Res. 32, 1792-1797.

Fairchild, G.B., Kohls, G.M., Tipton, V.J., 1966. The ticks of Panama (Acarina: Ixodoidea). In: Wenzel, W.R., Tipton, V.J. (Eds.), Ectoparasites of Panama. Field Museum of Natural History, Chicago, Illinois, pp. 167-219.

Garrigues, R., Camacho-Varela, P., Montoya, M., O’Donnell, P., Ramírez-Alán, O., Zook, J., 2018. Lista Oficial de las Aves de Costa Rica 2017-2018. Boletín de la Asociación Ornitológica de Costa Rica, San José, Costa Rica. https://www.zeledonia.com/ uploads/7/0/1/0/70104897/18-2-006-lista.pdf.

Hall, T., 1999. BioEdit: a user-friendly biological sequence alignment editor and analysis program for Windows 95/98/NT. Nucleic Acids Symp. Ser. 41, 95-98.

Kumar, S., Stecher, G., Tamura, K., 2016. MEGA 7: molecular Evolutionary Genetics Analysis version 7.0 for bigger datasets. Mol. Biol. Evol. 33, 1870-1874.

Labruna, M.B., Whitworth, T., Horta, M.C., Bouyer, D.H., McBride, J.W., Pinter, A., Popov, V., Gennari, S.M., Walker, D.H., 2004. Rickettsia species infecting Amblyomma cooperi ticks from an area in the state of Sao Paulo, Brazil, where Brazilian spotted fever is endemic. J. Clin. Microbiol. 42, 90-98.

Labruna, M.B., Mattar, V.S., Nava, S., Bermudez, S., Venzal, J.M., Dolz, G., Abarca, K., Romero, L., de Sousa, R., Oteo, J., Zavala-Castro, J., 2011. Rickettsioses in Latin 
America, Caribbean, Spain and Portugal. Rev. Mvz Cã³rdoba 16, 2435-2457.

Lee, J.H., Park, H.S., Jang, W.J., Koh, S.E., Kim, J.M., Shim, S.K., Park, M.Y., Kim, Y.W., Kim, B.J., Kook, Y.H., Park, K.H., Lee, S.H., 2003. Differentiation of rickettsiae by groEL gene analysis. J. Clin. Microbiol. 41, 2952-2960.

Mukherjee, N., Beati, L., Sellers, M., Burton, L., Adamson, S., Robbins, R.G., Moore, F., Karim, S., 2014. Importation of exotic ticks and tick-borne spotted fever group rickettsiae into the United States by migrating songbirds. Ticks Tick. Dis. 5, 127-134.

Norris, D.E., Klompen, J.S.H., Keirans, J.E., Black IV, W.C., 1996. Population genetics of Ixodes scapularis (Acari: ixodidae) based on mitochondrial 16S and 12S genes. J. Med. Entomol. 33, 78-89.

Novakova, M., Literak, I., Chevez, L., Martins, T.F., Ogrzewalska, M., Labruna, M.B., 2015. Rickettsial infections in ticks from reptiles, birds and humans in Honduras. Ticks Tick. Dis. 6, 737-742.

Ogrzewalska, M., Literak, I., Cardenas-Callirgos, J.M., Capek, M., Labruna, M.B., 2012. Rickettsia bellii in ticks Amblyomma varium Koch, 1844, from birds in Peru. Ticks Tick Dis. 3, 254-256.

Ogrzewalska, M., Martins, T., Capek, M., Literak, I., Labruna, M.B., 2013. A Rickettsia parkeri-like agent infecting Amblyomma calcaratum nymphs from wild birds in Mato Grosso do Sul, Brazil. Ticks Tick. Dis. 4, 145-147.

Ogrzewalska, M., Literak, I., Capek, M., Sychra, O., Alvarez, V., Calvo, B., Prudencio, C., Martins, T., Labruna, M.B., 2015. Bacteria of the genus Rickettsia in ticks (Acari: ixodidae) collected from birds in Costa Rica. Ticks Tick. Dis. 6, 478-482.

Ramos, D.G.D.S., Melo, A.L., Martins, T.F., Alves, A.D.S., Pacheco, T.D.A., Pinto, L.B., Labruna, M.B., Dutra, V., Aguiar, D.M., Pacheco, R.C., 2015. Rickettsial infection in ticks from wild birds from Cerrado and the Pantanal region of Mato Grosso, midwestern Brazil. Ticks Tick. Dis. 6, 836-842.

Regnery, R.L., Spruill, C., Plikaytis, B.D., 1991. Genotypic identification of rickettsiae and estimation of intraspecies sequence divergence for portions of two rickettsial genes. J. Bacteriol. 173, 1576-1589.

Rivas, J.J., Moreira-Soto, A., Alvarado, G., Taylor, L., Calderón-Arguedas, O., Hun, L. Corrales-Aguilar, E., Morales, J.A., Troyo, A., 2015. Pathogenic potential of a Costa Rican strain of 'Candidatus Rickettsia amblyommii' in Guinea pigs (Cavia porcellus) and protective immunity against Rickettsia rickettsii. Ticks Tick. Dis. 6, 805-811.

Santolin, I.D.A.C., Famadas, K.M., McIntosh, D., 2013. Detection and identification of Rickettsia agents in ticks collected from wild birds in Brazil by polymerase chain reaction-restriction fragment length polymorphism (PCR-RFLP) analysis. Rev. Bras. Med.Vet. 35, 68-73.

Troyo, A., Moreira-Soto, R.D., Calderon-Arguedas, Ó., Mata-Somarribas, C., Ortiz-Tello, J., Barbieri, A.R., Avendaño, A., Vargas-Castro, L.E., Labruna, M.B., Hun, L., Taylor, L., 2016. Detection of rickettsiae in fleas and ticks from areas of Costa Rica with history of spotted fever group rickettsioses. Ticks Tick. Dis. 7, 1128-1134.

Vaughn, M.F., Delisle, J., Johnson, J., Daves, G., Williams, C., Reber, J., 2014. Seroepidemiologic study of human infections with spotted fever group rickettsiae in North Carolina. J. Clin. Microbiol. 52, 3960-3966.

Webb Jr, J.P., Bennett, S.G., Challet, G.L., 1990. The larval ticks of the genus ixodes Latreille (Acari: ixodidae) of California. Bull. Soc. Vector Ecol. 15, 73-124.

Wilson, S., Hobson, K.A., Collister, D.M., Wilson, A.G., 2008. Breeding destinations and spring migration patterns of Swainson's thrush (Catharus ustulatus) at a Costa Rican stopover site. Auk 125.1, 95-104. 